IUCrJ

ISSN 2052-2525

BIOLOGY|MEDICINE

Accepted 23 December 2020

Edited by E. N. Baker, University of Auckland, New Zealand

Keywords: carbonic anhydrase; nitrite reductase; nitrous anhydrase; protein structure; enzyme mechanisms; inorganic chemistry.

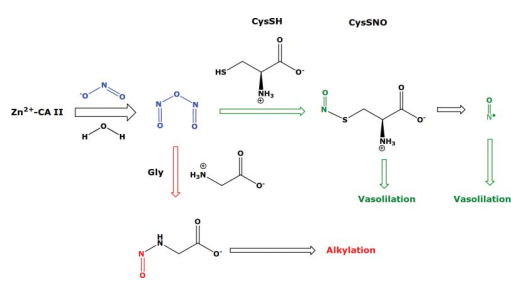

OPEN $\odot$ ACCESS

\section{Comment on the article Structure and mechanism of copper-carbonic anhydrase II: a nitrite reductase}

\author{
Dimitrios Tsikas*
}

Institute of Toxicology, Core Unit Proteomics, Hannover Medical School, Carl-Neuberg-Str. 1, Hannover, 30625, Germany. *Correspondence e-mail: tsikas.dimitros@mh-hannover.de

Carbonic anhydrase (CA) is one of the oldest, most efficient and best investigated ubiquitous $\mathrm{Zn}^{2+}$-containing enzymes. CA catalyzes a very simple but vital reaction, i.e. the hydration of carbon dioxide, in mammals, plants and bacteria (Meldrum \& Roughton, 1933). Rather surprisingly, over recent decades many additional physiological and pathological roles of CA have been discovered. A newly discovered CA activity is the bioactivation of inorganic nitrite $\left(\mathrm{O}=\mathrm{N}-\mathrm{O}^{-}\right)$to nitric oxide $(\mathrm{NO})$, a signaling multiplefunctional gaseous molecule in living organisms. Central to scientific research on CA has been its catalytic site that preferentially binds $\mathrm{Zn}^{2+}$, which is redox-inactive, and $\mathrm{Cu}^{2+}$, which is redox-active (Lindskog \& Nyman, 1964; Coleman, 1965). This topic is still of great scientific interest (Kim et al., 2020). In addition, and in contrast to $\mathrm{Zn}^{2+}, \mathrm{Cu}^{2+}$ binds to two different centers of CA which are differently affected by glutathione (GSH), the most abundant endogenous intra-cellular antioxidant with high specificity to $\mathrm{Zn}^{2+}, \mathrm{Cu}^{2+}$ and other divalent ions including $\mathrm{Hg}^{2+}$ (Tabbì et al., 2019). It can be expected that $\mathrm{Cu}^{2+}$ carrying CA is likely to exert not only the classical carbonic anhydrase activity, but may also be involved in redox-dependent reactions and mechanisms. For example, $\mathrm{Cu}^{2+}$ containing CA could oxidize $\mathrm{NO}$ to nitrite and higher nitrogen oxides $\left(\mathrm{NO}_{x}\right)$, as performed by the $\mathrm{Cu}^{2+}$-rich ceruloplasmin, or it could reduce nitrite to $\mathrm{NO}$ via intermediate $\mathrm{Cu}^{+}$-formation by GSH or ascorbic acid (Tabbì et al., 2019). Such a reaction is practically impossible for regular $\mathrm{Zn}^{2+}$-containing CA.

Recently, Andring and associates reported the crystal structure of copper (II)-bound human carbonic anhydrase II $\left(\mathrm{Cu}^{2+}\right.$-hCAII $)$ in complex with inorganic nitrite $(\mathrm{O}=\mathrm{N}-$ $\left.\mathrm{O}^{-}\right)$at $1.2 \AA$ resolution with two $\mathrm{Cu}^{2+}$ centers, analogous to bacterial nitrite reductases, and suggested that $\mathrm{Cu}^{2+}-$ hCAII can function as a nitrite reductase, yet without providing experimental evidence (Andring et al., 2020). In the scientific commentary on this article, Liljas stated that 'Andring et al. (2020) have been able to unravel the mystery' (Liljas, 2020), probably referring to the controversy that Aamand et al. (2009) found $\mathrm{Zn}^{2+}{ }_{-}$CAII to reduce nitrite to NO, whereas Andring et al. (2018) failed to detect $\mathrm{Zn}^{2+}$-CAIImediated reduction of nitrite to NO.

Our studies using bovine and human $\mathrm{Zn}^{2+}$-CAII demonstrated formation of $S$-nitrosoglutathione (GSNO) from nitrite and GSH suggesting nitrous anhydrase activity of $\mathrm{Zn}^{2+}$ CAII, which was not inhibitable by the CA-inhibitors acetazolamide or dorzolamide (Hanff et al., 2016; Zinke et al., 2016). We observed formation of NO only in the presence of L-cysteine (CysSH), most likely due to the intermediate formation of $S$-nitrosocysteine (CysSNO), which can readily and abundantly decompose to $\mathrm{NO}$ in the presence of $\mathrm{Cu}^{+}$ (Tsikas et al., 2002).

$\mathrm{Cu}^{2+}$ ions were found to bind to $\mathrm{Zn}^{2+}$-CAII isolated from human erythrocytes at a site other than the active site and inhibited the exchange of water from the enzyme without affecting the equilibrium rate of hydration of $\mathrm{CO}_{2}$ (Tu et al., 1981). This observation may suggest that classical CA inhibitors such as acetazolamide may inhibit the carbonic anhydrase activity of CA by tightly binding to the CAII-bound $\mathrm{Zn}^{2+}$, through the sulfone amide group, but not to the second $\mathrm{Cu}^{2+}$-binding site. This could be an explanation for our observation that neither acetazolamide nor dorzolamide inhibited the nitrous anhydrase activity of bovine and human CAII (Hanff et al., 2016; Zinke et al., 2016).

Andring et al. (2020) stated that 'recent reports have shown that CAII can also reduce nitrite $\left(\mathrm{NO}_{2}^{-}\right)$to nitric oxide (NO)... (Andring et al., 2018; Aamand et al., 2009; Hanff et 
al., 2018)', that 'However, when dialyzed with ethylenediaminetetraacetic acid (EDTA), the enzyme retained its carbonic anhydrase activity yet lost its nitrite reductase activity (Hanff et al., 2018)', and that 'Furthermore, if this bovine CAII was dialyzed against EDTA, the nitrite reductase activity was ablated indicating that a metal cofactor within the bovine blood was needed for the CAII-dependent nitrite reductase activity (Andring et al., 2018; Hanff et al., 2018).'. We wish to point out this mistake in the paper by Andring et al. (2020). In the paper referred to above (i.e., Hanff et al., 2018), we did not report that CAII is a nitrite reductase, but we explicitly stated that we measured nitrous anhydrase activity of bovine and human CAII and CAIV, and did not use EDTA (i.e. Hanff et al., 2018).

\section{References}

Aamand, R., Dalsgaard, T., Jensen, F. B., Simonsen, U., Roepstorff, A. \& Fago, A. (2009). Am. J. Physiol. Heart Circ. Physiol. 297, H2068H2074.
Andring, J. T., Kim, C. U. \& McKenna, R. (2020). IUCrJ, 7, 287-293. Andring, J. T., Lomelino, C. L., Tu, C., Silverman, D. N., McKenna, R. \& Swenson, E. R. (2018). Free Radical Biol. Med. 117, 1-5.

Coleman, J. E. (1965). Biochemistry, 4, 2644-2655.

Hanff, E., Böhmer, A., Zinke, M., Gambaryan, S., Schwarz, A., Supuran, C.T. \& Tsikas, D. (2016). Amino Acids, 48, 1695-706.

Hanff, E., Zinke, M., Böhmer, A., Niebuhr, J., Maassen, M., Endeward, V., Maassen, N., \& Tsikas, D. (2018). Anal. Biochem. 550, 132-136.

Kim, J. K., Lee, C., Lim, S. W., Adhikari, A., Andring, J. T., McKenna, R., Ghim, C.-M. \& Kim, C. U. (2020). Nat. Commun. 11, 4557.

Liljas, A. (2020). IUCrJ, 7, 144-145.

Lindskog, S. \& Nyman, P. O. (1964). Biochim. Biophys. Acta, 85, 462474.

Meldrum, N. U. \& Roughton, F. J. (1933). J. Physiol. 80, 113-142.

Tabbì, G., Magrì, A. \& Rizzarelli, E. (2019). J. Inorg. Biochem. 199, 110759.

Tsikas, D., Sandmann, J. \& Frölich, J. C. (2002). J. Chromatogr. B, 772, 335-346.

Tu, C., Wynns, G. C. \& Silverman, D. N. (1981). J. Biol. Chem. 256, 9466-9470.

Zinke, M., Hanff, E., Böhmer, A., Supuran, C. T. \& Tsikas, D. (2016). Amino Acids, 48, 245-255. 